\title{
Characterization and Classification of Soils of Jirang Block in Meghalaya Plateau
}

\author{
R.K. Jena ${ }^{1 *}$, V.P. Duraisami², R. Sivasamy², R. Shanmugasundaram², R. Krishnan², \\ S. Padua ${ }^{1}$, S. Bandyopadhyay ${ }^{1}$, S. Ramachandran ${ }^{1}$, P. Ray ${ }^{1}$, \\ P. Deb Roy ${ }^{1}$, S.K. Singh ${ }^{3}$ and S.K. Ray \\ ${ }^{1}$ ICAR-National Bureau of Soil Survey and Land Use Planning, Regional Centre, Jorhat-785004, India \\ ${ }^{2}$ Tamil Nadu Agricultural University, Coimbatore-641003, India \\ ${ }^{3}$ ICAR-National Bureau of Soil Survey and Land Use Planning, Amravati Road, \\ Nagpur-440033, India
}

\begin{abstract}
The Meghalaya plateau occupying a major portion of state of Meghalaya remains as an important part of the ancient Deccan plateau. A detailed soil survey (1:10,000 scale) of the Jirang block of Ri-Bhoi district was carried out using IRS-P6 LISS IV and Cartosat-1 images. Typical pedons representing major landforms of the study area viz., denudational hills, plateau and inter hill valley plain developed from granite-gneiss occurring under varying land use were characterized and classified. The soils were deep to very deep, dark greyish brown to red in colour, extremely acid to moderately acid in reaction and high in organic carbon; the latter decreased with depth. Soils on high denudational hills, highly dissected upper and lower plateau and low dissected lower plateau are highly weathered (kandic horizons) with base saturation $<35 \%$ and are classified as Ultisols. Soils on low denudational hills are highly weathered Alfisols. Soils of moderately dissected lower plateau and those on upper valley region are both Alfisols, but the latter has lower base saturation than the former. The soils of the lower valley are Alfisols with an aquic moisture regime.
\end{abstract}

Keywords: Alfisols, detailed soil survey, Inceptisols, kandic horizon, Ultisols

\section{Introduction}

Knowledge on the potential of soil resources and its limitations, present use and the methods of management for sustained production, is vital for the use of soil for crop production purposes (Bhattacharyya et al. 2013). Lack of such knowledge results in indiscriminate use of resources coupled with wrong management leading to degradation which is a concern for planners, researchers and farmers alike (Sharma 2006). Hence, timely and reliable information on soils with respect to their nature, extent, spatial distribution, potential and limitation is very important (Arunkumar et.al. 2002).

The North Eastern Region (NER) of India is characterized by very complex geological and geomorphic formations with heavy rainfall which is commensurate with various types of soils formed on different landforms (Roy 1976; Thompson et al. 1998).

It is known that the differences in soil characteristics associated with different landforms are

*Corresponding Author Email: roomeshjena@gmail.com usually attributed to differences in the runoff, erosion and deposition processes which affect the process of soil genesis. The pedogenic characteristics of some subgroups of Inceptisols in the highlands of the Darjeeling Himalayan region (Pal et al.1984), Alfisols and Ultisols in Sikkim forest division (Gangopadhyay et al.1986) and in Mizoram (Singh et al.1991) have been reported. The distribution and characteristics of moderate to strongly acid subgroups of Oxisols, Inceptisols and Entisols were reported in the high altitude region of Meghalaya (Nair and Chamuah 1988). These Oxisols were reclassified later in the subgroups of Ultisols by defining sub-surface horizons as kandic taking into consideration the values of apparent ECEC and CEC (Bhattacharyya et al. 1994). The same criteria were used to identify kandic horizons in soils of Manipur by Sen et al. (1994). Large Number of soil families suggests more variation in soils of Assam followed by Arunachal Pradesh, Tripura and Mizoram. Expectedly higher elevation ranges of Arunachal Pradesh, Meghalaya and Manipur contain dominant proportions of Ultisols on 1:2, 50,000 scale which is for regional level planning (Bhattacharyya et al. 2013). The productivity potential of these soils is limited by intrinsic 
characteristics, so understanding of these soils as influenced by landscape features is of great significance. Soil information on Meghalaya is limited to small scales only where mapping units comprises association of family. Site specific agricultural planning is limited using these maps. Large scale information on soil resources for the state is necessary for need based farm/ village level land use planning. Keeping this in view an effort was made to study the characteristics and classification of the soils in Jirang block, Ri-Bhoi district, Meghalaya. The present study was undertaken with a view to establish soil-landform relationship and the variation of morphological, physical and chemical properties of the soil under different land use systems.

\section{Materials and Methods}

Study area

Jirang block is located between $25^{\circ} 47^{\prime} 17.16^{\prime \prime} \mathrm{N}$ to $26^{\circ} 05^{\prime} 22.56^{\prime \prime} \mathrm{N}$ latitude and $91^{\circ} 20^{\prime} 40.56^{\prime \prime} \mathrm{E}$ to $91^{\circ} 51^{\prime} 41.4^{\prime \prime}$ E longitude in Ri-Bhoi district, Meghalaya and covers an area of $714 \mathrm{~km}^{2}$ (Fig. 1). The study area falls under Meghalaya or Shillong Plateau physiographic division. The major geology is granite-gneiss and topography of the area comprises of undulating terrain with a maximum elevation of $980 \mathrm{~m}$ on south-eastern side and minimum elevation of $60 \mathrm{~m}$ on the north-western side. In general, the ground surface slopes towards north-western direction with topographical variations and intermittent hills, plateaus and valley plains. It falls under agro-ecological sub-regions 15.2 and 17.1 (Velayutham et al. 1999) and characterized by udic soil moisture and hyperthermic soil temperature regimes (Soil Survey Staff 2014). It is characterized by hot and moist summers and cool winters belonging to subtropical climate. The mean summer temperature rises to a high of $26.4^{\circ} \mathrm{C}$ and mean winter temperature reaches $13.8^{\circ} \mathrm{C}$. The average annual rainfall of the area is about $2395 \mathrm{~mm}$ which is confined mostly to April to October period and scanty in the dry winter months from November to February. The average rainy days per annum is 176 .

Preparation of base map, soil survey and laboratory methods

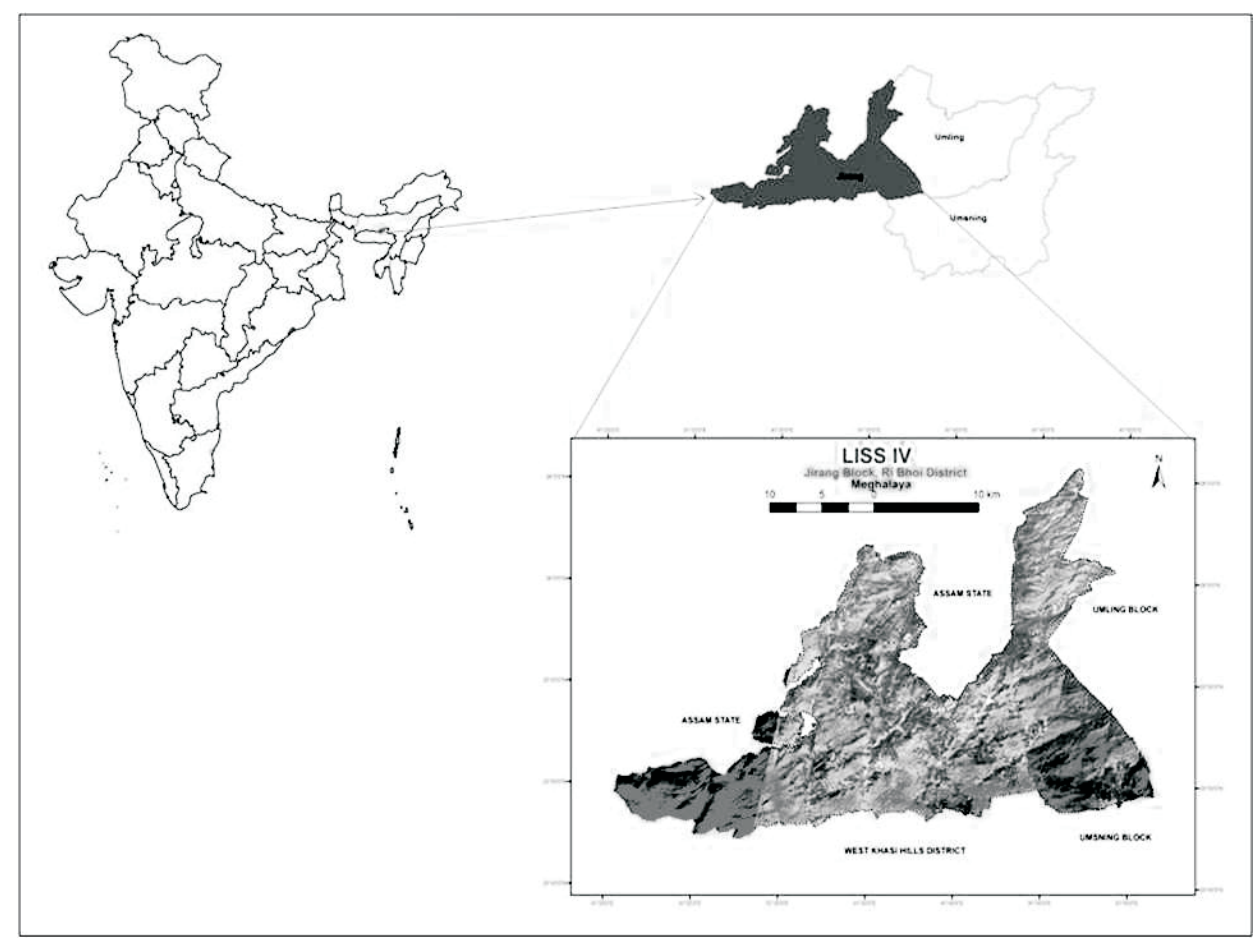

Fig. 1. Location map of the study area 
Base map was prepared using IRS-P6 LISS IV and Cartosat-1 images to delineate the landform units and landscape ecological units (LEUs).The delineation of landforms as well as land use land cover (LULC) was carried out by visual interpretation techniques. Geomorphic features and land use-land cover classes were interpreted based on key image elements such as shape, tone or colour, pattern, shadow, association and texture. Digital elevation model (DEM) of $10 \mathrm{~m}$ resolution was generated from Cartosat-1 stereo pair and hill shade was generated from the Cartosat-1 DEM using ArcGIS software. Slope map was also generated from Cartosat DEM (10 m). All these maps were compiled in a GIS environment to get the base map. Eight landforms were obtained from denudational high hills (>33\% slope) to lower valleys (1-3\% slope) (Table 1). Soil profiles and auger observations from selected transects were studied in such a way that soil survey and mapping observations have been taken in all landform units and the location of soil profiles were recorded using GPS. Horizon-wise morphological properties including depth, colour, structure, texture, graveliness, consistence, occurrence of nodules, etc., were described following USDA soil survey manual (Soil Survey Staff 2014). Soil samples were collected horizon-wise, air dried and processed ( $2 \mathrm{~mm}$ sieve) for various analyses following standard methods. The soils were analysed for their physical and chemical properties following methods described by Black (1965) and Jackson (1950). Eight soil series were identified in the block using the method employed by Reddy (2006). Representative master profiles for each series were identified which also represented the corresponding landform unit.

Table 1. Site characteristics of different soils

\begin{tabular}{|c|c|c|c|c|c|}
\hline $\begin{array}{c}\text { Pedon } \\
\text { No }\end{array}$ & Soil Series & Physiography & Slope gradient (\%) & Drainage & $\begin{array}{c}\text { Present land } \\
\text { use }\end{array}$ \\
\hline $\mathrm{P} 21$ & Umtyngar & $\begin{array}{l}\text { Denudational high } \\
\text { hills }\end{array}$ & $>33$ & Well & Forest \\
\hline P16 & Umsong & $\begin{array}{l}\text { Denudational low } \\
\text { hills }\end{array}$ & $25-33$ & Well & Forest \\
\hline P17 & Umtang & $\begin{array}{l}\text { Highly dissected } \\
\text { upper plateau }\end{array}$ & $10-15$ & Well & $\begin{array}{l}\text { Shifting } \\
\text { cultivation }\end{array}$ \\
\hline P3 & Umsophanon & $\begin{array}{l}\text { Highly dissected } \\
\text { lower plateau }\end{array}$ & $8-10$ & Well & $\begin{array}{l}\text { Shifting } \\
\text { cultivation }\end{array}$ \\
\hline P24 & Sukurbaria & $\begin{array}{l}\text { Moderately dissected } \\
\text { lower plateau }\end{array}$ & $5-8$ & $\begin{array}{l}\text { Moderately } \\
\text { Well }\end{array}$ & Paddy \\
\hline P9 & Umkynsier & $\begin{array}{l}\text { Lowly dissected } \\
\text { lower plateau }\end{array}$ & $5-8$ & $\begin{array}{l}\text { Moderately } \\
\text { Well }\end{array}$ & Paddy \\
\hline P4 & New Jirang & Upper valley & $1-3$ & $\begin{array}{l}\text { Moderately } \\
\text { Well }\end{array}$ & Paddy \\
\hline $\mathrm{P} 13$ & Nongladew & Lower valley & $1-3$ & $\begin{array}{l}\text { Imperfectly } \\
\text { drained }\end{array}$ & Paddy \\
\hline
\end{tabular}

\section{Results and Discussion}

\section{Morphological Properties}

The surface soils varied from dark greyish brown
(10YR 4/2) to yellowish red (5YR 4/6) whereas the subsurface layers are generally reddish in colour. Fine iron concretions are observed which is indicative of high rainfall (Bhattacharyya et al. 1996). In pedons 24 and 13, gleyed 
Table 2. Physical characteristics of the soils

\begin{tabular}{|c|c|c|c|c|c|c|}
\hline Horizon & $\begin{array}{l}\text { Depth } \\
\text { (cm) }\end{array}$ & $\begin{array}{l}\text { Sand } \\
(2.0- \\
0.05) \\
\end{array}$ & $\begin{array}{c}\text { Total (\% } \\
\text { Silt } \\
(0.05- \\
\mathbf{0 . 0 0 2}) \\
\end{array}$ & $\underset{(<\mathbf{0 . 0 0 2})}{\text { Clay }}$ & $\begin{array}{l}\text { Sand/silt } \\
\text { ratio }\end{array}$ & $\begin{array}{c}\text { Bulk } \\
\text { Density } \\
\left(\mathrm{Mg} / \mathrm{m}^{3}\right)\end{array}$ \\
\hline \multicolumn{7}{|c|}{ Pedon 3 Umsophanon series : Fine-loamy, mixed, hyperthermic Typic Hapludults } \\
\hline Ap & $0-16$ & 53.2 & 18.3 & 28.5 & 2.9 & 1.18 \\
\hline Bw1 & $16-43$ & 51 & 16.5 & 32.5 & 3.09 & 1.18 \\
\hline Bw2 & $43-77$ & 51 & 16 & 33 & 3.18 & 1.33 \\
\hline 2Bt1 & $77-120$ & 51.1 & 14.4 & 34.5 & 3.54 & 1.33 \\
\hline $3 \mathrm{Bt} 2$ & $120-147$ & 50.6 & 16.4 & 33 & 3.08 & 1.33 \\
\hline \multicolumn{7}{|c|}{ Pedon 4 New Jirans series : Fine-loamy, mixed, hyperthermic Flurentic Dystrudepts } \\
\hline Ap1 & 0-20 & 18.1 & 45.9 & 36 & 0.39 & 1.25 \\
\hline $2 \mathrm{AC} 1$ & $20-60$ & 48.7 & 32.8 & 18.5 & 1.48 & 1.11 \\
\hline $3 \mathrm{AC} 2$ & $60-80$ & 65.7 & 15.3 & 19 & 4.29 & 1.18 \\
\hline 4Bw1 & $80-120$ & 59.7 & 19.3 & 21 & 3.09 & 1.25 \\
\hline $5 B w 2$ & $120-135$ & 51.9 & 22.1 & 26 & 2.34 & 1.05 \\
\hline \multicolumn{7}{|c|}{ Pedon 9 Umkynsier series : Fine-loamy, mixed, hyperthermic Typic Hapludults } \\
\hline Ap1 & $0-14$ & 45.7 & 28.8 & 25.5 & 1.58 & 1.25 \\
\hline $2 A p 2$ & $14-37$ & 28.5 & 48 & 23.5 & 0.59 & 1.11 \\
\hline 3Bt1 & $37-58$ & 28.3 & 31.2 & 40.5 & 0.91 & 1.18 \\
\hline $3 \mathrm{Bt} 2$ & $58-87$ & 28.8 & 29.2 & 42 & 0.98 & 1.25 \\
\hline 4BC1 & $87-123$ & 54.9 & 18.6 & 26.5 & 2.95 & 1.54 \\
\hline $5 \mathrm{BC} 2$ & $123-150$ & 49.1 & 22.9 & 28 & 2.14 & 1.43 \\
\hline \multicolumn{7}{|c|}{ Pedon 13 Nongladew series : Fine, mixed, hyperthermic Typic Endoaqualfs } \\
\hline Apg1 & $0-30$ & 16.8 & 44.7 & 38.5 & 0.37 & 1.33 \\
\hline Apg2 & $30-60$ & 23.3 & 40.2 & 36.5 & 0.57 & 1.54 \\
\hline 2Bwg1 & $60-80$ & 13.8 & 45.2 & 41 & 0.30 & 1.54 \\
\hline $2 \mathrm{Btg} 1$ & 80-110 & 4.5 & 40.5 & 55 & 0.11 & 1.43 \\
\hline 2Bwg2 & $110-140$ & 13.2 & 45.3 & 41.5 & 0.29 & 1.54 \\
\hline 3Bwg3 & $140-165$ & 20.6 & 38.9 & 40.5 & 0.52 & 1.43 \\
\hline \multicolumn{7}{|c|}{ Pedon 16 Umsophanon series : Fine, mixed, hyperthermic Typic Hapludults } \\
\hline A1 & $0-12$ & 32.3 & 38.7 & 29 & 0.83 & 1.43 \\
\hline $2 \mathrm{Bt} 1$ & $12-25$ & 16.8 & 32.2 & 51 & 0.52 & 1.25 \\
\hline $2 \mathrm{Bt} 2$ & $25-48$ & 11 & 28 & 61 & 0.39 & 1.25 \\
\hline $2 \mathrm{Bt} 3$ & $48-72$ & 8.8 & 32.7 & 58.5 & 0.27 & 1.25 \\
\hline $2 \mathrm{Bt} 4$ & $72-92$ & 7.1 & 36.4 & 56.5 & 0.19 & 1.25 \\
\hline $2 \mathrm{Bt} 5$ & $92-115$ & 7.2 & 32.8 & 60 & 0.22 & 1.25 \\
\hline $2 \mathrm{Bt} 6$ & $115-150$ & 8.8 & 30.2 & 61 & 0.29 & 1.25 \\
\hline \multicolumn{7}{|c|}{ Pedon 17 Umsophanon series : Fine, kaolinitic, hyperthermic Typic Kandiudults } \\
\hline Ap & $0-20$ & 45 & 20.5 & 34.5 & 2.19 & 1.33 \\
\hline $\mathrm{Bt} 1$ & $20-48$ & 36.4 & 17.1 & 46.5 & 2.12 & 1.33 \\
\hline $2 \mathrm{Bt} 2$ & $48-78$ & 32.9 & 19.1 & 48 & 1.72 & 1.18 \\
\hline $2 \mathrm{Bt} 3$ & 78-107 & 35.5 & 19.5 & 45 & 1.82 & 1.18 \\
\hline $2 \mathrm{Bt} 4$ & $107-136$ & 37.9 & 19.6 & 42.5 & 1.93 & 1.25 \\
\hline \multicolumn{7}{|c|}{ Pedon21 Umsophanon series : Fine, koolinitic, hyperthermic Typic Kandihumults } \\
\hline A1 & $0-25$ & 24 & 28.5 & 47.5 & 0.84 & 1.11 \\
\hline $\mathrm{Bw}$ & $25-57$ & 22.3 & 23.7 & 54 & 0.94 & 1.11 \\
\hline Bt1 & $57-102$ & 22.3 & 21.2 & 56.5 & 1.05 & 1.25 \\
\hline Bt2 & $102-150$ & 20.2 & 22.8 & 57 & 0.88 & 1.11 \\
\hline \multicolumn{7}{|c|}{ Pedon 24 Sukurbarid series : Fine, loomy, mixed, hyperthermic Flurentic Endoaquepts. } \\
\hline Ap & $0-26$ & 11 & 45.5 & 43.5 & 0.24 & 1.33 \\
\hline Bwg1 & $26-59$ & 13.7 & 42.3 & 44 & 0.32 & 1.43 \\
\hline 2Bwg2 & $59-81$ & 41.5 & 29.5 & 29 & 1.40 & 1.43 \\
\hline $3 \mathrm{BC}$ & $81-117$ & 88.5 & 1 & 10.5 & 88.5 & 1.54 \\
\hline 4Bwg3 & $117-140$ & 56.6 & 18.4 & 25 & 3.07 & 1.54 \\
\hline
\end{tabular}


horizon with mottles are observed in the sub-surface. These soils are foun in lowl dissected plateau and valley plains due to the prevalence of excessive wet environment under fluctuating ground water condition which is a common phenomenon in waterlogged soils of North Eastern Region (Bhattacharyya et al. 2003). The structure was predominantly subangular blocky in all pedons which may be attributed to the presence of higher quantities of clay fraction (Sharma et. al. 2004). The texture of the surface horizons varied from loam to clay. Identification of relatively well developed structure in the sub-surface horizon (compared to the surface horizons) supported by enriched clay distribution indicated the presence of cambic horizon (Bw) in pedons 24,4 and 13 . Increase in clay content in the lower layers of most of the pedons (21, 16, 17, 3 and 9) is attributed to clay illuviation.

\section{Physical Properties}

The sand content of the soils varied from 11 to $53.2 \%$ in the surface layers, whereas it varied from 4.5 to $88.5 \%$ in the sub-surface layers (Table 2). Total sand content decreased with depth of soil in pedons 21, 16, 17 and 3, whereas it increased with depth of soil in pedons 5 and 7 . The distribution of total sand is irregular in pedons 9 and 13 . The clay content of the soils varied from 25.5 to $47.5 \%$ in the surface horizons whereas it varied from 10.5 to $61.0 \%$ in the sub-surface. The increase in clay content in pedons 21,16 , 17,3 and 13 with soil depth indicated illuviation of clay in the hills, plateaus and lower valley regions (Bhattacharyya et al. 1998). Irregular distribution of clay in pedons 24, 9 and 4 was observed. The sand/silt ratio in the lower-most horizons of these pedons indicated lithological discontinuity (Sidhu et al. 1976). This may be attributed to topographical features of lower plateaus and upper valley (Anand et al. 1977) and as a result of colluvial deposition of various cycles facilitated by heavy stream flow and gravity over the time rather than pedologic (Ande and Senjobi 2010) processes. The bulk density of pedons varied from 1.05 to $1.54 \mathrm{Mg} \mathrm{m}^{-3}$. It was observed that increase in bulk density with depth in pedons 3 , 24, 9 and 13 is attributed to lower organic matter, more compaction and less aggregation (Singh and Agrawal 2005), whereas irregular pattern of bulk density was observed in other pedons.

\section{Chemical properties}

Soil reaction ( $\mathrm{pH}$ 1:2.5 soil:water ratio) of the pedons varied from 4.2 to 5.9 (Table 3 ). Soils of the pedons $21,16,17,3,24,9$ and 4 are extremely to strongly acidic $(\mathrm{pH}$ 4.2 to 5.6) while the soils of pedon 13 are very strongly to moderately acidic ( $\mathrm{pH}$ 4.9-5.9). In all the cases, $\mathrm{pH}$ values increased down the profile. The $\mathrm{pH}$ in $\mathrm{KCl}(N)$ is always lower than that of water. However the negative values for ? $\mathrm{pH}\left(\mathrm{pH}_{\mathrm{KCl}}-\mathrm{pH} \mathrm{H} \mathrm{H}_{2} \mathrm{O}\right)$ indicated the existence of negatively charged colloidal particles. The extractable acidity of the soils varied from 0.14 to $2.23 \mathrm{cmol}\left(\mathrm{p}^{+}\right) \mathrm{kg}^{-1}$ and it decreased with soil depth except in pedon 4 where reverse trend was observed. Extractable $\mathrm{Al}^{3+}$ has the highest share towards the extractable acidity which is highest in pedon 1 and lowest in pedon 13. The organic carbon content of the soils varied from 0.4 to $19.8 \mathrm{~g} \mathrm{~kg}^{-1}$ and is high at surface and decreased with soil depth. The highest amount of OC $\left(19.8 \mathrm{~g} \mathrm{~kg}^{-1}\right)$ is observed in the surface soil of pedon 4 on upper valley and lowest in the surface soils of pedons 16 and $13\left(10 \mathrm{~g} \mathrm{~kg}^{-1}\right)$. Pedon 4, area representing recently cleared forest, now under paddy cultivation, had higher OC in the surface soil. Similarly in current shifting cultivation areas also high OC content is observed (Pedon 17 and 3).

Soil CEC varied from 2.2 to $17.1 \mathrm{cmol}(\mathrm{p}+) \mathrm{kg}^{-1}$ apparently due to variation in clay content which can be due to the presence of pseudo-aggregates of sesquioxidic nature and amorphous oxides of iron and aluminum which form coating on clay fractions (Bhaskar and Subbaiah 1995).

Among the extractable bases, $\mathrm{Ca}^{2+}$ is dominant in pedons 16,9 and 13 whereas $\mathrm{Mg}^{2+}$ is present in higher amount in pedons 16 and 13 . The $\mathrm{Na}^{+}$and $\mathrm{K}^{+}$values however do not vary much within the pedons. The total extractable bases are high in pedon 13 and show an irregular distribution with depth. This may be due to the accumulation of bases in the lower valley position by runoff water from the surrounding areas (Gangopadhyay et al. 2001). Relatively low CEC in the study area might be due to dominance of clay minerals with low CEC and presence of hydrous oxides of iron and aluminium in the soils (Sarkar et al. 2002). The base saturation of these soils varied from 10 to $87 \%$ and it is highest in pedon 13 . 


\begin{tabular}{|c|c|c|c|c|}
\hline$\stackrel{0}{e}$ & $\infty \tilde{\sim} \approx \tilde{\sim} \tilde{c}$ & mষ্ণ & 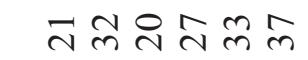 & q $n$ in $n \mathbb{N}$ \\
\hline 苞 & $\simeq a r a$ & 큐음 & $\because \therefore a ㅇ ㅡ ㅇ ㅡ$ & 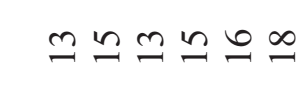 \\
\hline 远界 & 류를 & 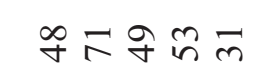 & Fñ $\tilde{n} \tilde{\sim} \stackrel{\sim}{\sim}$ & 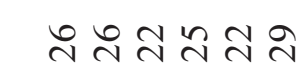 \\
\hline$\bigcup_{\text {U工工 }}^{0}$ & 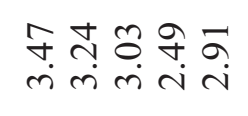 & 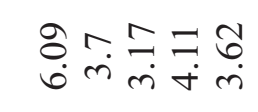 & 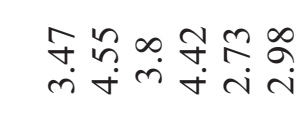 & 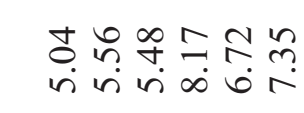 \\
\hline U & ñ⿻ & 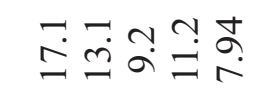 & 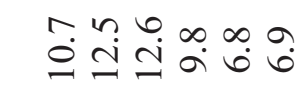 & 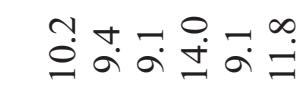 \\
\hline$\frac{0}{\frac{0}{0}}$ & 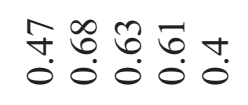 & 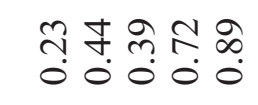 & 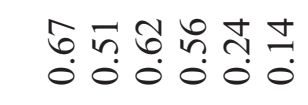 & ڤ̂े \\
\hline$\stackrel{+}{\frac{1}{2}}$ & 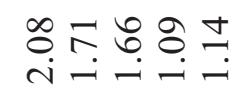 & تn & 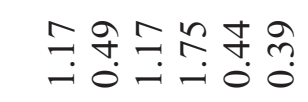 & 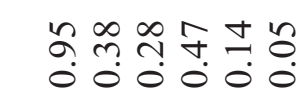 \\
\hline & $\begin{array}{lllll}0 & + & \ddots & \infty & 0 \\
0 & 0 & 0 \\
0 & 0 & 0 & 0 & 0\end{array}$ & 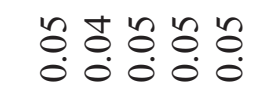 & 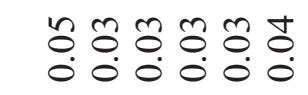 & 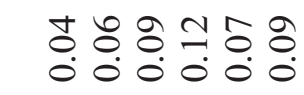 \\
\hline 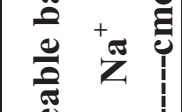 & 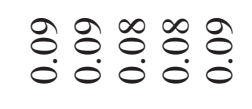 & $=\dot{0}-\tilde{\hat{0}} \overline{0}$ & 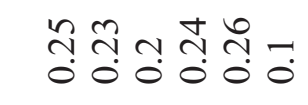 & 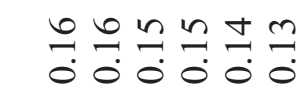 \\
\hline$\sum_{\bar{x}}^{\bar{E}} \sum^{+}$ & 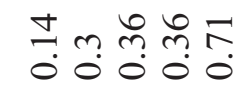 & 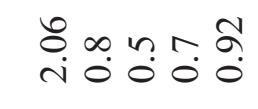 & 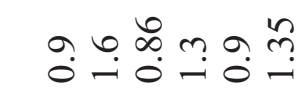 & 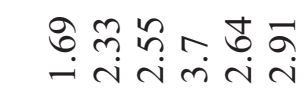 \\
\hline & $\because \neg$\begin{tabular}{lll}
$\infty$ & $\infty$ & $\infty$ \\
\hdashline & $\infty$ & $\infty$ \\
0 & 0 & 0 \\
0 & 0
\end{tabular} & 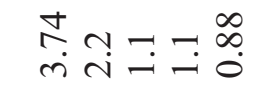 & 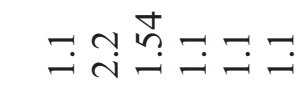 & 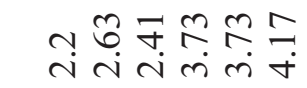 \\
\hline 0 & nân & 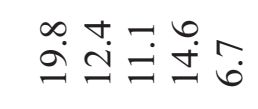 & $\stackrel{+}{\dot{\Xi}} \stackrel{\infty}{\sigma} \sigma \stackrel{+}{\sigma} \stackrel{m}{-}$ & 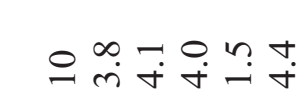 \\
\hline & 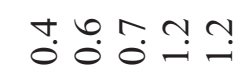 & 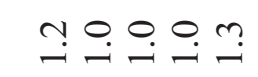 & m & 공 $9 \stackrel{\infty}{-} \stackrel{0}{-}$ \\
\hline 플 & 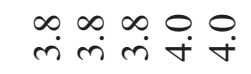 & 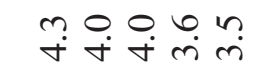 & 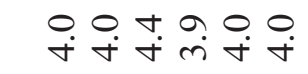 & 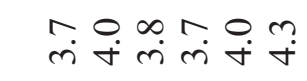 \\
\hline 氕 & $\begin{array}{l}\forall \\
\forall \\
\forall\end{array}$ & 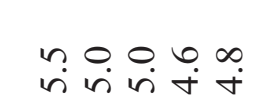 & 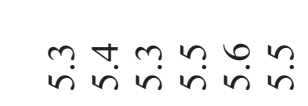 & 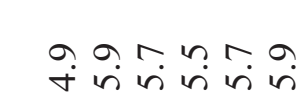 \\
\hline & 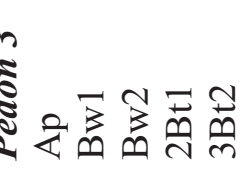 & 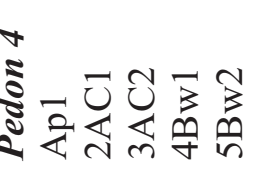 & 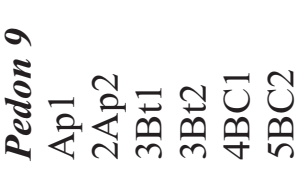 & 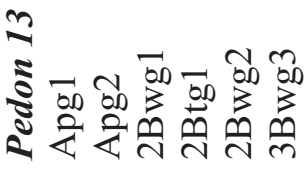 \\
\hline
\end{tabular}




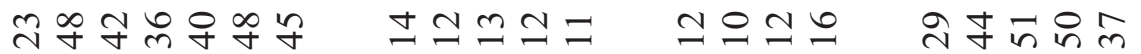

$\exists a \infty+\infty a \infty \quad \infty n+\forall m \quad \sim n+m \quad \underline{n}=0 \simeq$

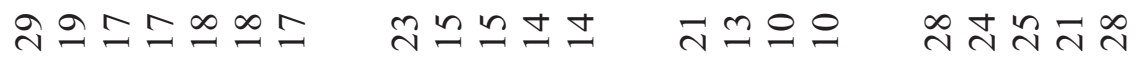

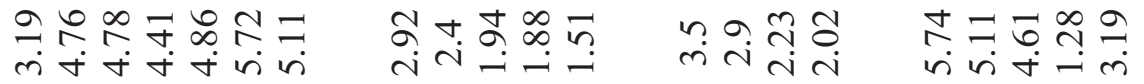

må

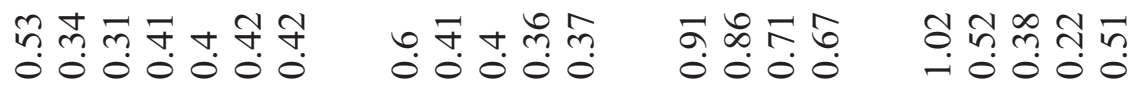

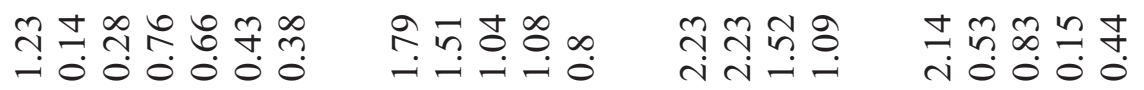

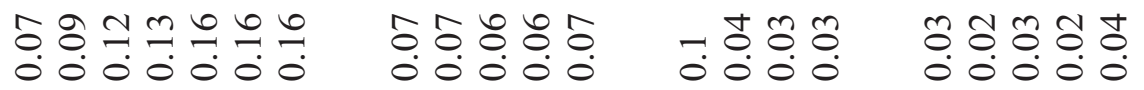

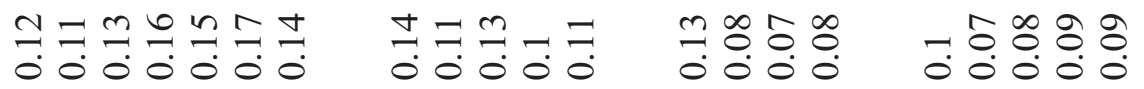

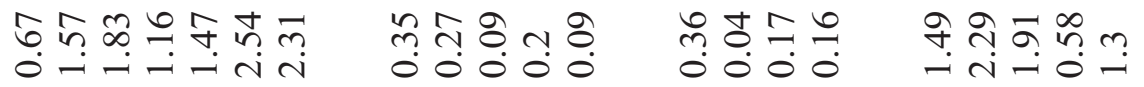

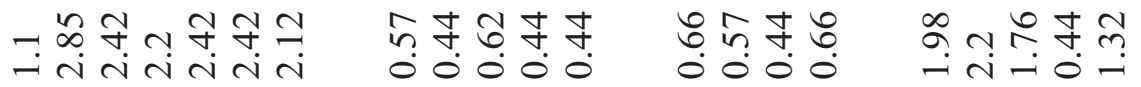

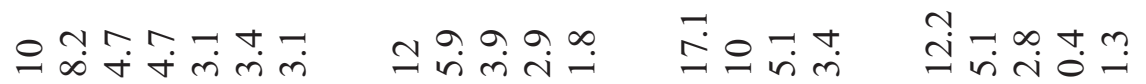

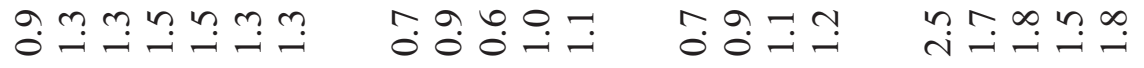

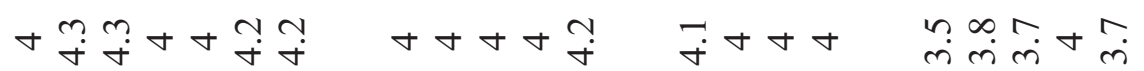

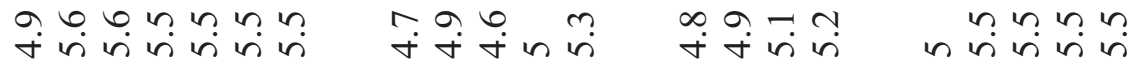

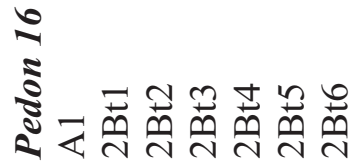

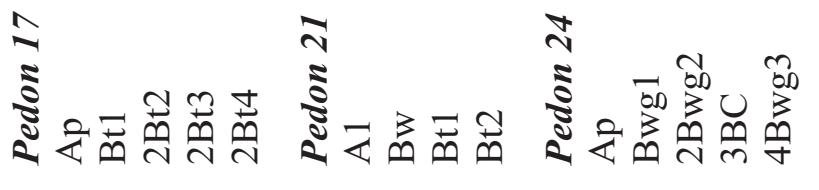




\section{Soil classification}

The soils have been classified following the latest criteria laid down in soil Taxonomy using field and laboratory data (Soil Survey Staff 2014). Pedons 24 and 4 showed the development of colour and/or structural cambic (Bw) horizons and thus qualify for Inceptisols. At suborder level pedon 24 is grouped as aquepts due to chroma value $<2$ and the presence of redoximorphic features. At great group level this qualifies for Endoaquepts. Whereas pedon 4 is grouped as Udepts due to presence of udic soil moisture regime. The base saturation of soils is less than $60 \%$ by ammonium acetate $\left(\mathrm{NH}_{4} \mathrm{OAc}\right)$ at a depth between 25 and 75 $\mathrm{cm}$ from the mineral soil surface in pedon 4. It justifies Dystrudepts at great group level. Pedons 24 and 4 have more OC $(>0.2 \%)$ content at a depth of $125 \mathrm{~cm}$ below the surface and it decreased irregularly between a depth of $25 \mathrm{~cm}$ and $125 \mathrm{~cm}$ below the mineral soil surface and hence these soils qualify for Fluventic at sub group level. Pedons 21, 17, 3 and 9 have base saturation $<35 \%$ so they are classified as Ultisols. At suborder level pedons 17, 3 and 9 are grouped into Udults due to their occurance in udic soil moisture regime. At great group level due to presence of kandic (Bt) horizon with apparent $\mathrm{CEC}<16 \mathrm{cmol}\left(\mathrm{p}^{+}\right) \mathrm{kg}^{-1}$ and apparent ECEC $<12 \mathrm{cmol}\left(\mathrm{p}^{+}\right) \mathrm{kg}^{-1}$ pedon 17 is grouped into Kandiudults, whereas pedon 21 is grouped into Humults at sub order level due to presence of $>12 \mathrm{~kg} / \mathrm{m}^{2}$ organic carbon between the mineral soil surface and a depth of $100 \mathrm{~cm}$. It is classified as Kandihumults at great group level due to presence of kandic horizon (Bt) with apparent CEC $<16$ $\operatorname{cmol}\left(\mathrm{p}^{+}\right) \mathrm{kg}^{-1}$ and apparent ECEC $<12 \mathrm{cmol}\left(\mathrm{p}^{+}\right) \mathrm{kg}^{-1}$. Pedons 9 and 3 are grouped into Hapludults at great group level due to presence of argillic horizons (apparent CEC $>16 \mathrm{cmol}\left(\mathrm{p}^{+}\right)$ $\mathrm{kg}^{-1}$ and apparent ECEC $\left.>12 \mathrm{cmol}\left(\mathrm{p}^{+}\right) \mathrm{kg}^{-1}\right)$.

Pedons 16 and 13 have argillic/kandic horizon (Bt) with base saturation $>35 \%$ so they qualify for Alfisols. Both the pedons are grouped into Udalfs at suborder level due to presence of Udic moisture regime. Pedon 16 has argillic horizons (Bt) with apparent CEC $>16 \mathrm{cmol}\left(\mathrm{p}^{+}\right) \mathrm{kg}^{-1}$ and thus qualifies for Hapludalfs at great group level. Pedon 13 shows redoximorphic features and the chroma of 2 or less in the matrix so at suborder level it is grounded as Aqualfs. At great group level these soils are grouped into Endoaqualfs. As all the pedons are not qualifying under any other sub group and are classified as Typic at sub group level except pedons 24 and 4 which are Fluventic due to an irregular decrease in OC content between a depth of 25 to $125 \mathrm{~cm}$ from the mineral soil surface and the OC content of more than $0.2 \%$ and more at a depth below $125 \mathrm{~cm}$ from the mineral soil surface.

Generally the soils in this region are highly weathered owing to high rainfall conditions. These are indicated by the lower values of clay CEC and clay ECEC (Table 3). Soils in the denudational high hills are highly weathered due to very low apparent $\mathrm{CEC}$ and $\operatorname{ECEC}(<16$ and $<12 \mathrm{cmol}\left(\mathrm{p}^{+}\right) \mathrm{kg}^{-1}$ respectively) in the soil control section and due to the presence of higher OC $\left(>12 \mathrm{~kg} \mathrm{~m}^{-2}\right)$ owing to forest vegetation and thus as Kandihumults is justified (Singh et al. 2005). Soils in the highly dissected upper plateau also contain low activity of clay but with lower OC $\left(<12 \mathrm{~kg} \mathrm{~m}^{-2}\right)$ compared to the soils of denudational high hills. This is evidenced from the fact that these soils belong to Kandiudults owing to relatively lower organic matter content compared to denudational high hills. Soils of highly dissected lower plateau and lowl dissected lower plateau had clay CEC more than $16 \mathrm{cmol}\left(\mathrm{p}^{+}\right) \mathrm{kg}^{-1}$ the soils attained the weathering of Ultisols, but of a lower degree Hapludults. The reason for extensive occurrence of Ultisols may be due to the geomorphically stable landscapes over acid crystalline rocks (Boul et al. 2003). However in the denudational low hills the soils are much less weathered as the base saturation is more than $35 \%$ and the landscape and soils appear to be less stable for higher degree of weathering. The occurrence of Ultic Hapludalfs in West Garo Hills district of Meghalaya (Singh et al. 2005) and Typic Hapludalfs in Phek district of Nagaland, Goalpara district of Assam and Senapati district of Manipur was also reported (Maji et al. 2004; Vadivelu et al. 2004; and Sen et al. 2006). The moderately dissected lower plateau and upper valley regions are the depositional landscapes and thereby produced weathering surfaces comparable to a "cambic" horizon only (Bhaskar et al. 2004). The occurrence of deep soils belonging to Ultisols, Alfisols and Inceptisols on slopes of elevated landforms suggests that the materials displaced from the summits are not transported to long distances but deposited in the adjoining lower landscapes (Bhattachayya et al. (2002). However, it is interesting that in the lower valley region the soils have argillic horizon may be due to stability of the landscape and uniform cropping system.

\section{Conclusion}

The study showed that the soils in the hilly region qualify as Ultisols or Alfisols. The plateaus had mainly Ultisols, Alfisols and Inceptisols and valleys are associated 
with Alfisols (endosaturation). The formation of diverse group of soils could be attributed to the effect of topography, vegetation and climate leading to various pedogenic processes. In highly dissected upper and lower plateau and lowl dissected upper plateau, soils are highly weathered and presence of active clays suggests that these soils may be exten used for agro-forestry and plantations. Owing to the presence of higher bases, the valley soils can be used for crop diversification with strategic agronomic measures viz., liming acid soils and improving drainage by adopting scientific terrace cultivation. The information generated can also help the researchers, farmers and planners to comprehend the natural resources of Jirang block for future planning.

\section{References:}

Anand, R.R., Sehgal, J.L. and Sharma, P.K. (1977). Genesis and classification of some soils of the Malwa alluvial plain. Proceedings of the National Academy of Sciences 43, Part B, Nos. 1 \& 2, 44 54.

Ande, O.T. and Senjobi, B. (2010). Lithologic discontinuity and pedogenetic characterization on an aberrant toposequence associated with a rock hill in South Western Nigeria. International Journal of the Physical Sciences 5, 596-604.

Arunkumar. V., Natarajan, S. and Sivasamy, R. (2002). Characterisation and classification of soils of Lower Palar . Manimuthar Watershed of Tamil Nadu. Agropedology 12, 97-103.

Black, C.A. (1965). Methods of Soil Analysis, Part 1 and 2 (American Society of Agronomy Inc., Madison, Wisconsin, USA).

Bhaskar, B.P. and Subbaiah, G.V. (1995). Genesis, characterization and classification of laterite and associates soils along the east coast of Andhra Pradesh. Journal of Indian Society of Soil Science 43, 107-112.

Bhaskar, B.P., Saxena, R.K., Vadivelu, S.V., Baruah, U., Butte, P.S. and Dutta, D.P. (2004). Pedogenesis in high altitude soils of Meghalaya plateau. Agropedology 14(1), 9-23.

Bhattacharyya, T., Sen, T.K., Singh, R.S., Nayak, D.C. and Sehgal, J.L. (1994). Morphology and classification of Ultisols with kandic horizon in North Eastern region. Journal of the Indian Society of Soil Science 42, 301-306.
Bhattacharyya, T., Sehgal, J. and Sarkar, D. (1996). Soils of Tripura for Optimising Land Use, their Kinds, Distribution and Suitability for Major Field Crops and Rubber. NBSS Publ. 65 a \& c. Nagpur, India.

Bhattacharyya, T., Mukhopadhyoy, S., Buruah, U. and Chamuah, G. S. (1998). Need of soil study to determine degradation and landscape stability. Current Science 74, 42-47.

Bhattacharyya, T., Ram Babu, Sarkar, D., MandaI, D., MandaI, C. And Nagar, A.P. (2002). Soil erosion of Tripura, a model for soil conservation and crop performance. NBSS Publication No. 97. NBSS\&LDP, Nagpur.

Bhattacharyya, T., Pal, D.K. and Vaidya, P.H. (2003). Soil landscape model for suitable cropping pattern in Tripura. Part I. Soil resources in Tripura - their extent, nature and characteristics. DST Project Report, NBSS\&LUP(ICAR) Nagpur, 114.

Bhattacharyya, T., Pal, D. K., Mandal, C., Chandran, P., Ray, S. K., Sarkar, D., Velmourougane, K., Srivastava, A., Sidhu, G. S., Singh, R. S., Sahoo, A. K., Dutta, D., Nair, K. M., Srivastava, R., Tiwary, P., Nagar, A. P. and Nimkhedkar, S. S. (2013). Soils of India: historical perspective, classification and recent advances. Current Science 104, 1308-1323.

Buol, S.W., Southward, R.J., Graham, R.C. and McDaniel, P.A. (2003). Soil Genesis and Classification. Iowa state Press, State Avenue, Ames, Iowa.

Gangopadhyay, S.K., Debanath, N.C. and Banerjee, S.K. (1986). Characteristics of some high altitude soils of Sikkim forest division. Journal of the Indian Society of Soil Science 34, 830-838.

Gangopadhyay, S.K., Bhattacharyya, T. and Sarkar, D. (2001). Rubber growing soils of Tripura - Their characteristics and classification. Journal of the Indian Society of Soil Science 49, 164-170.

Jackson, M.L. (1950). Soil Chemical Analysis. (Indian Edition), Prentice Hall of India Ltd. Delhi.

Maji, A.K., Baruah,U., Dubey, P. N.,Verma,T.P.,Butte,P.S., Shilu, K. and Angami,V. (2004). Soil Series of Nagaland. NBSS Publ.109, 126.

Nair, K.M. and Chamuah, G.S. (1988). Characteristics and classification of some pine forest soils of Meghalaya. Journal of the Indian society of Soil Science 36, 142-145.

Pal, D.K., Nath,S. and Banerjee,S.K. (1984). Pedological characteristics of some soils of the Dmjeeling 
Himalayan region . Journal of the Indian Society of Soil Science 32, 716-724.

Reddy, R.S. (2006). Methodology for correlation of soil series in soil survey and mapping. Agropedology 16, 1-11.

Roy. B.B. (1976). Red and lateritic soils of West Bengal. Proceedings National Academy Science of India 46, 85-92.

Sarkar, D., Baruah, U., Gangopadhyay, S.K., Sahoo, A.K. and Velayutham, M. (2002). Characteristics and classification of soils of Loktak catchment area of Manipur for sustainable land use planning. Journal of the Indian Society of Soil Science 50, 196-204.

Sen, T.K., Chamuah, G.S. and SeghaI, J.L. (1994). Occurrence and characteristics of some kandi soils in Manipur. Journal of the Indian Society of Soil Science 42, 297-300.

Sen, T.K., Baruah, U., Sarkar,D., Maji,A.K. and Patil,V.P. (2006). Soil Series of Manipur. NBSS Publ.134, 53.

Sharma, V.K., Sharma, P.D., Sharma, S.P., Acharya, C.L. and Sood, R.K. (2004). Characterization of cultivated soils of Neogal watershed in north-west Himalayas and their suitability for major crops. Journal of the Indian Society of Soil Science 52, 63-68.

Sharma, P.D. (2006). Soil Science Research - Vision 2025. Indian Society of Soil Science News Letter 20, p. 1.

Sidhu, P.S., Hall, G.F and Sehgal, J.L. (1976). Studies on some soils at varying stages of pedogenic development in the central Punjab. Journal of Research (PAU) 13, 23-33.
Singh, O.P., Datta, B. and Rao, C.N. (1991). Pedochemical characterisation and genesis of soils in relation to altitude in Mizoram. Journal of the Indian Society of Soil Science 39, 739-750.

Singh, I.S. and Agrawal, H.P. (2005). Characterization, genesis and classification of rice soils of Eastern Region of Varanasi, Uttar Pradesh. Agropedology 15, 29-38

Singh, R.S., Baruah, U., Sarkar, D., Butte, P.S. and Gajbhiye, K.S. (2005). Soil Series of Meghalaya. NBSS Publ.121, 86.

Soil Survey Staff. (1999). Soil Taxonomy: A basic system of Soil Classification for making and interpreting soil surveys. Second edition. Agricultural Handbook Number 436. United States Department of Agriculture and National Resources Conservation Service, Washington D.C. USA.

Soil Survey Staff. (2014). 'Keys to Soil Taxonomy', Twelfth Edition. (U.S.D.A.: Natural Resources Conservation Service, Washington, D.C.).

Thompson J.A., Bell J. C. and Zanner W.C. (1998). Hydrology and hydric soil extent within a Mollisol catena in Southeastern Minnesota. Soil Science Society of America Journal 62, 11261133.

Vadivelu, S., Sen, T.K., Bhaskar, B.P., Baruah, U., Sarkar, D., Maji, A.K. and Gajbhiye, K.S.(2004). Soil Series of Assam. NBSS Publ.101, 229.

Velayutham, M., D.K. Mandal, C. Mandal and J. Sehgal. (1999). Agro-ecological subregions of India for planning and developments, Nagpur, India. NBSS Publ. 35, 372.

Received : May, 2016 Accepted : June, 2016 